\title{
Biosynthesis, characterization and antimicrobial activity of copper oxide nanoparticles (CONPs) produced using brown alga extract (Bifurcaria bifurcata)
}

\author{
Y. Abboud $\cdot$ T. Saffaj $\cdot$ A. Chagraoui $\cdot$ \\ A. El Bouari · K. Brouzi • O. Tanane • \\ B. Ihssane
}

Received: 11 April 2013/Accepted: 10 May 2013/Published online: 4 June 2013

(C) The Author(s) 2013. This article is published with open access at Springerlink.com

\begin{abstract}
Recently, biosynthesis of nanoparticles has attracted scientists' attention because of the necessity to develop new clean, cost-effective and efficient synthesis techniques. In particular, metal oxide nanoparticles are receiving increasing attention in a large variety of applications. However, up to now, the reports on the biopreparation and characterization of nanocrystalline copper oxide are relatively few compared to some other metal oxides. In this paper, we report for the first time the use of brown alga (Bifurcaria bifurcata) in the biosynthesis of copper oxide nanoparticles of dimensions $5-45 \mathrm{~nm}$. The synthesized nanomaterial is characterized by UV-visible absorption spectroscopy and Fourier transform infrared spectrum analysis. X-ray diffraction confirms the formation and the crystalline nature of copper oxide nanomaterial. Further, these nanoparticles were found to exhibit high antibacterial activity against two different strains of bacteria
\end{abstract}

Y. Abboud $(\bowtie) \cdot$ A. Chagraoui · A. El Bouari · O. Tanane Laboratoire de Physico-Chimie des Matériaux Appliqués, Faculté des sciences Ben M'sik, Université Hassan II Mohammedia, Casablanca, Morocco

e-mail: Youabboud@yahoo.fr

T. Saffaj

Centre Universitaire Régional d'Interface, Université Sidi Mohamed Ben Abdallah, B.P 2626, route d'Imouzzar, Fez, Morocco

\section{K. Brouzi}

Laboratoire Energetique, Materiaux et Environnement Ecole Supérieure de Technologie, Université Mohammed V Agdal Rabat, Sale, Morocco

B. Ihssane

Laboratoire de Chimie Organique Appliquée, Faculté des Sciences et Techniques, Université Sidi Mohamed Ben Abdallah, B.P 2626, route d'Imouzzar, Fez, Morocco
Enterobacter aerogenes (Gram negative) and Staphylococcus aureus (Gram positive).

Keywords Green synthesis - Copper oxide nanoparticles . Brown alga $\cdot$ Antimicrobial activity

\section{Introduction}

Unlike bulk materials, nanoparticles have been intensively studied over the last decade due to their characteristics: physical, chemical, electronic, electrical, mechanical, magnetic, thermal, dielectric, optical and biological properties (Schmid 1992; Daniel and Astruc 2004). Therefore, nanoparticles are considered as building blocks of the next generation of technology with applications in many industrial sectors. In particular, metal oxide nanoparticles are receiving increasing attention in a large variety of applications. Metal oxide nanoparticles are of interest because of their unique optical, electronic and magnetic properties. The oxides of transition metals are an important class of semiconductors, which have applications in magnetic storage media, solar energy transformation, electronics, gas sensors and catalysis (Ramgir et al. 2013; Jani et al. 2013; Shalana et al. 2013; Montferrand et al. 2013; Ahmadi et al. 2011). Although various physical and chemical methods have been extensively used to produce nanocrystalline copper oxide such as microemulsion method (Nassar and Husein 2007), arc-submerged nanoparticle synthesis system (Kao et al. 2007), flame-based aerosol methods (Chiang et al. 2012), sonochemical (Vijayakumar et al. 2001), hydrothermal (Zhang et al. 2006) and solid-state techniques (Wang et al. 2004), the stability and the use of toxic chemicals are subjects of paramount concern. The use of toxic chemicals on the 
surface of nanoparticles and non-polar solvents in the synthesis procedure limits their applications in clinical fields. Therefore, development of clean, biocompatible, nontoxic and eco-friendly methods for nanoparticles synthesis deserves merit. The interest in this field has shifted toward 'green' chemistry and bioprocess approach. These approaches focus on utilization of environment-friendly, costeffective and biocompatible reducing agents for synthesis of copper oxide nanoparticles (CONPs). Review of literature revealed that synthesis of CONPs using microorganisms and plant extract has been unexplored; there are only a very few reports on the use of yeast, fungi, bacteria or plant extract for synthesizing CONPs (Honary et al. 2012; Rahman et al. 2009; Gunalan et al. 2012) compared to the great number of articles for other metals, and none using the brown alga (Bifurcaria bifurcata). Therefore, in the present work, attempts were made to utilize the potential of this brown alga as a biofactory for the CONPs synthesis. Interestingly, this is the first report on the synthesis of highly stable CONPs using marine alga (Bifurcaria bifurcata). The process is described and different analytical techniques were used including UV-visible spectroscopy (UV-vis), Fourier transform infrared spectroscopy (FTIR), transmission electron microscopy (TEM) and X-ray diffraction analysis (XRD). Furthermore, the bacterial effect of CONPs was also analyzed by disc diffusion method.

\section{Materials and methods}

\section{Preparation of alga extract}

Bifurcaria bifurcata, a brown alga, collected on rocks at about $3 \mathrm{~m}$ depth from Morocco's Atlantic Coast in Rose Marie near Rabat, was extensively washed with deionized water, until the $\mathrm{pH}$ of the wash solution was equal to deionized water, and subsequently dried in a oven at $60{ }^{\circ} \mathrm{C}$ overnight. It is then finely powdered and stored. About $10 \mathrm{~g}$ of powdered alga was transferred into a $150 \mathrm{ml}$ beaker containing $50 \mathrm{ml}$ double distilled water, mixed well on rotary shaker for $1 \mathrm{~h}$ and then boiled for $15 \mathrm{~min}$. The extract obtained was filtered and used as a reducing agent and stabilizer.

Synthesis of copper oxide nanoparticles

Synthesis of colloidal CONPs has been done using the following procedures; typically $2 \mathrm{ml}$ of alga extract was added dropwise into $20 \mathrm{ml}$ of $1 \mathrm{mM}$ aqueous solution of copper(II) sulfate with constant stirring at $100-120{ }^{\circ} \mathrm{C}$. Within few hours, the deep blue solution gradually became colorless and then turned slowly to brick red coloration which changed to dark after vigorous stirring for $24 \mathrm{~h}$.
Characterization of copper oxide nanoparticles

The bioreduction of copper (II) ion in solution was monitored using Perkin-Elmer Lambda 2 double beam UVvisible spectrometer against distilled water as blank. After that, the solution mixture (alga extract and copper sulfate) was centrifuged at 5,500 rpm for $15 \mathrm{~min}$ and subsequently redispersed in distilled water to get rid of any uncoordinated biological molecules. This process of centrifugation was repeated thrice to ensure better separation of the CONPs. The purified dried powders were then used for further characterization. The FTIR spectral measurements were carried out on Bruker Tensor-27 spectrophotometer and the XRD analysis was obtained using Bruker D8 Advance powder X-ray diffractometer. The morphology of the nanoparticles was analyzed using the high-resolution image obtained with Tecnai G2 transmission electron microscope.

Antibacterial activity of synthesized copper nanoparticles

The CONPs synthesized using alga extract were tested for antimicrobial activity by agar disc diffusion method against pathogenic bacteria Enterobacter aerogenes (Gram-negative) and Staphylococcus aureus (Gram-positive). The pure cultures of bacteria were subcultured on nutrient agar medium. Each strain was swabbed uniformly onto the individual plates using sterile cotton swabs. Filter paper discs (Whatman no. 3, $6 \mathrm{~mm}$ diameter) were sterilized by autoclaving. $20 \mu \mathrm{l}$ of nanoparticle solution was loaded onto each paper disc and allowed to air dry. The dry discs were placed on the previously inoculated agar. After incubation at $37{ }^{\circ} \mathrm{C}$ for $24 \mathrm{~h}$, the different levels of zone of inhibition of bacteria were measured.

\section{Results and discussion}

The formation of CONPs was initially confirmed visually and by using UV-visible spectroscopy technique which has been frequently used to characterize the synthesized metal and metal oxide nanoparticles. The change in color of the reaction mixture (Fig. 1) due to surface plasmon resonance phenomenon provides a convenient signature to indicate the formation of CONPs in the reaction mixture (Krithiga et al. 2013).

Figure 2 shows the UV-vis absorption spectra recorded for alga extract before (curve A) and after (curve B) the reaction with $1 \mathrm{mM}$ copper(II) sulfate. As seen, the UVvisible absorption spectrum of the solution containing alga extract before addition of copper sulfate used as a control (curve A) shows two peaks of maximum absorption at 245 


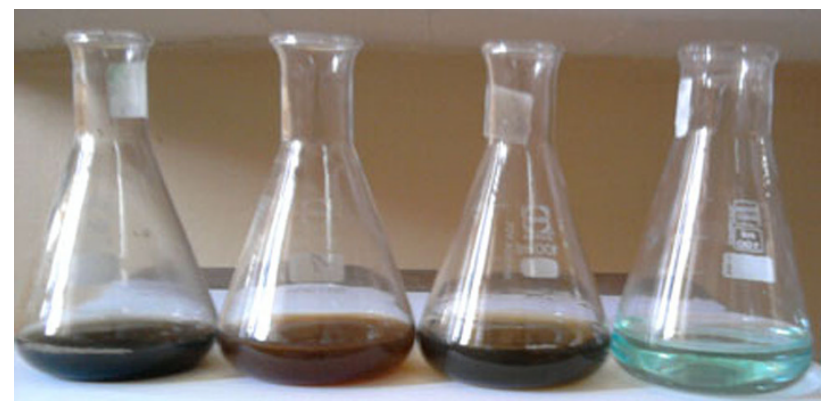

Fig. 1 Color change during the phytoreduction of $\mathrm{CuSO}_{4}$ into CONPs at the beginning and after $48 \mathrm{~h}$ of reaction

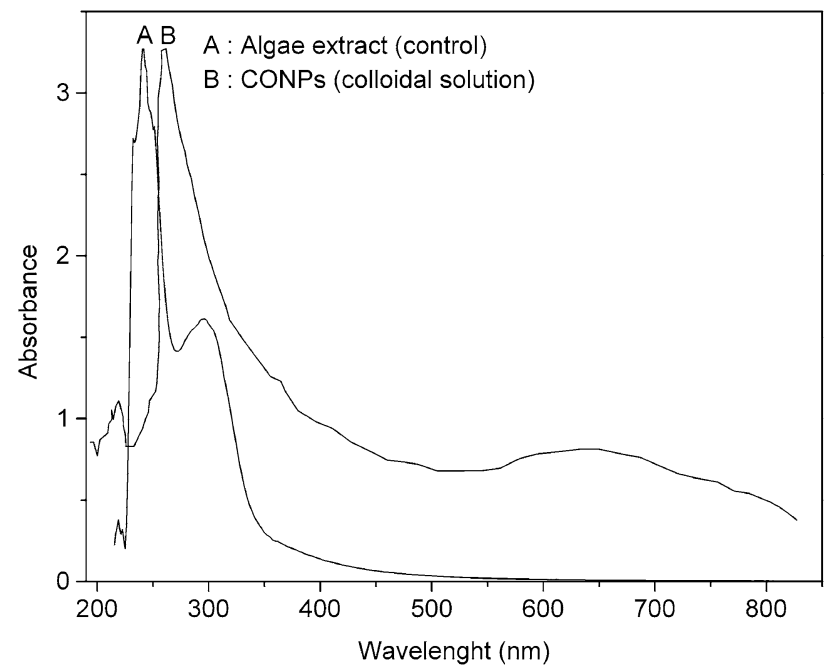

Fig. 2 UV-vis absorption spectrum of CONPs prepared with alga extract. A Alga extract as control; $B$ solution formed at the end of the reaction

and $290 \mathrm{~nm}$ characteristic of diterpenoids that are very abundant in the brown algae Bifurcaria bifurcata (Valls et al. 1993; Combaut and Piovetti 1983). After addition of copper sulfate (curve B), it is clearly seen that these bands disappeared and new bands were observed in the solution. The colloidal suspensions after reduction (curve B) show two strong resonance, one at about $260 \mathrm{~nm}$ which are attributed to the formation of cuprous oxide nanoparticles $\left(\mathrm{Cu}_{2} \mathrm{O}\right)$ (Borgohain et al. 2002) and another weak broad resonance centered at about $650 \mathrm{~nm}$, which is assigned to the formation of cupric oxide nanoparticles $(\mathrm{CuO})$ (Yin et al. 2005).The observed changes in the spectrum reflect the characteristic pattern of CONPs formation by reducing copper ions with water-soluble diterpenoids present in the algae extract. These results clearly suggest the formation of a mixed $\mathrm{Cu}_{2} \mathrm{O}$ and $\mathrm{CuO}$ phase in colloidal solution that is in conformity with available literature. It is important to note that lot of reports in the literature on synthesis of copper/CONPs by various techniques have commonly resulted in a mixture of $\mathrm{CuO}$ and $\mathrm{Cu}_{2} \mathrm{O}$ nanocrystals
[Yin et al. 2005; Rahman et al. 2009; Swarnkar et al. 2009). The shape and size of the resultant particles were elucidated with the help of TEM (Fig. 3). Nanoparticles observed from the micrograph majority are spherical with a small percentage of elongated particles. It is observed that there is a variation in particle size. Most of the nanoparticles ranged from 5 to $45 \mathrm{~nm}$ in size, and the average size estimated was $20.66 \mathrm{~nm}$ according to the size distribution shown in (Fig. 4). Further, evidence for the biosynthesis of CONPs is provided by the XRD pattern of the synthesized nanopowder illustrated in Fig. 5. It can be seen that the asprepared sample clearly indicates the presence of two crystalline phase indices, monoclinic cupric oxide $(\mathrm{CuO})$

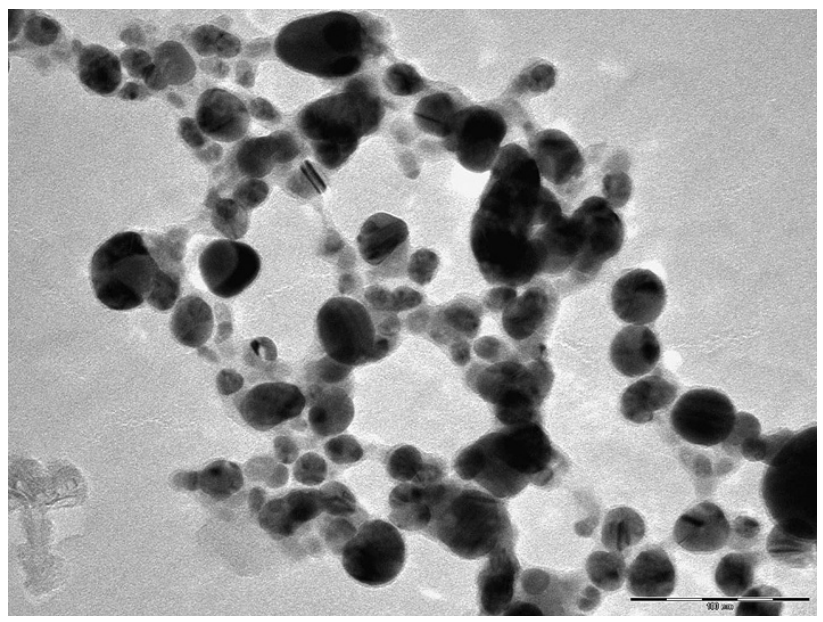

Fig. 3 TEM image of CONPs synthesized from the alga extract

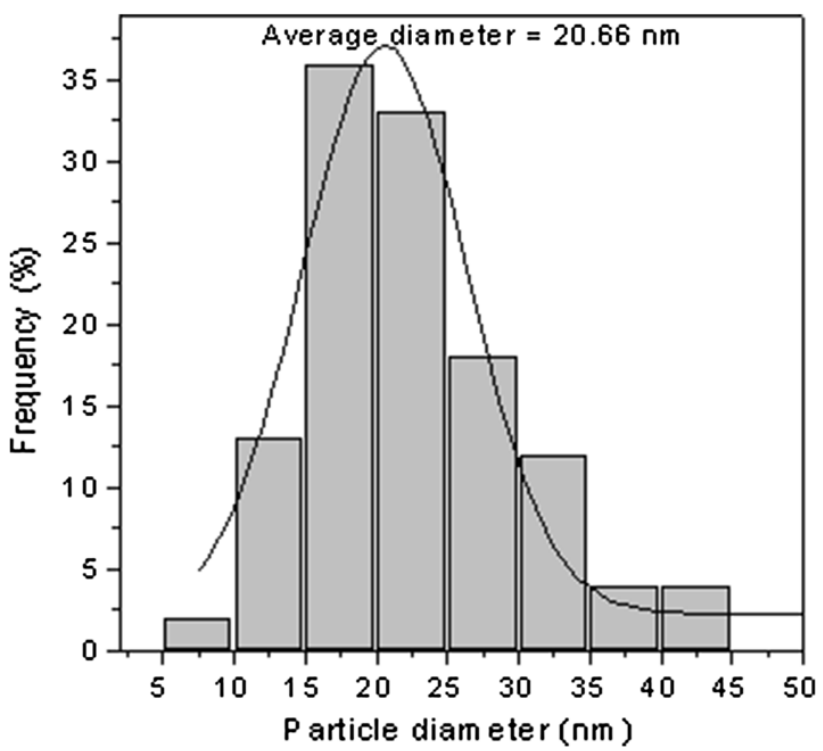

Fig. 4 Histogram of the particle size distribution of CONPs synthesized from the alga extract 


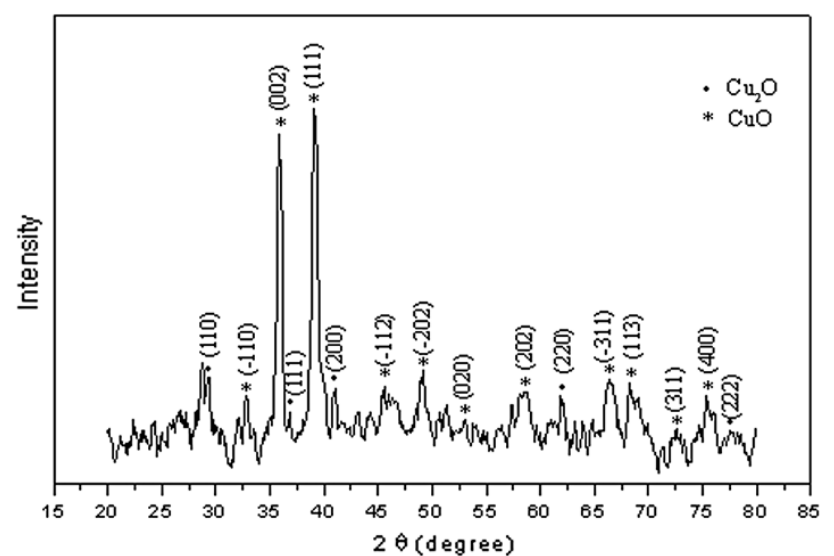

Fig. 5 XRD spectrum of CONPs synthesized from the alga extract

and cubic cuprous oxides $\left(\mathrm{Cu}_{2} \mathrm{O}\right)$. The peak positions with $2 \theta$ values of $29.4^{\circ}, 36.8^{\circ}, 42.1^{\circ}, 61.9^{\circ}$ and $77.6^{\circ}$ are indexed as (110), (111), (200), (220) and (222) planes which are in good agreement with those of powder $\mathrm{Cu}_{2} \mathrm{O}$ obtained from the International Center of Diffraction Data card (JCPDS file no. 05-0667) confirming the formation of a crystalline cubic phase $\mathrm{Cu}_{2} \mathrm{O}$ with a cuprite structure (Kooti and Matouri 2010; Srivata et al. 2013), while the peaks at $32.8^{\circ}, 35.9^{\circ}, 39.1^{\circ}, 46.3^{\circ}, 49.1^{\circ}, 52.9^{\circ}, 58.7^{\circ}$, $66.6^{\circ}, 68.3^{\circ}, 72.6^{\circ}$ and $75.5^{\circ}$ can be assigned to $(-111)$, (002), (111), (-112), (-202), (020), (202), (-311), (113), (311) and (400) planes which are matched with the values of monoclinic phase $\mathrm{CuO}$ reported in the literature (Volanti et al. 2008) and with the respective "JCPDS" (Joint Committee on Powder Diffraction Standards card no. 45-0937). Therefore, the formation of both $\mathrm{Cu}_{2} \mathrm{O}$ and $\mathrm{CuO}$ nanocrystals in the sample was confirmed by the above XRD studies. This result is in agreement with that of UVvisible absorption spectroscopy. Higher intensity at 20 values of $35.9^{\circ}$ and $39.1^{\circ}$ respectively indicates that the mixed phase has major proportion of $\mathrm{CuO}$ with the highly oriented crystalline $\mathrm{CuO}$ phase. Thus, the amount of cuprous oxide is less than that of cupric oxide. The average particle size was estimated using the well-known Scherrer formula, $D=k \lambda / \beta \cos \theta$, where $D$ is particle diameter, $k$ is a constant equals $1, \lambda$ is wavelength of $\mathrm{X}$-ray source $(0.1541 \mathrm{~nm}), \beta$ is the full width at half maximum (FWHM) and $\theta$ is the half diffraction angle. The particles sizes obtained from XRD line broadening was found to be around $18.34 \mathrm{~nm}$ which well correlates with that obtained from TEM. Thus the XRD pattern proves to be strong evidence in favor of the UV-vis spectra and TEM images for the presence and size of copper oxide nanoparticles.

FTIR measurements of both the aqueous alga extract and the synthesized dried CONPs were carried out to identify the possible biomolecules responsible for the reduction, capping of and efficient stabilization of the bio-

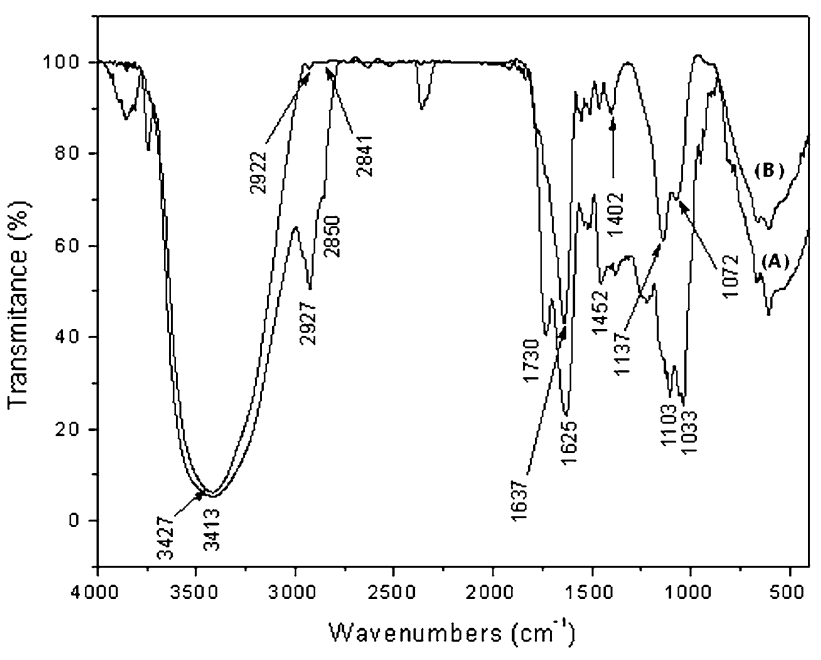

Fig. 6 FTIR spectrums $A$ alga extract; $B$ CONPs nanoparticles

reduced CONPs. The FTIR spectra of the alga extract and the synthesized CONPs are shown in Fig. $6 a$ and b. The alga extract displays a number of adsorption peaks, reflecting its complex nature. A wider range of compounds has been reported from the brown alga of the genus Bifurcaria bifurcata, when diterpenoids were the predominantly reported compound classes [Blunt et al. 2005; Amico 1995). As shown in Fig. 6a, diterpenoids from Bifurcaria bifurcata can be identified by the strongest peaks of hydroxyl at $3,413 \mathrm{~cm}^{-1}, \alpha, \beta$ - unsaturated ketone band at $1,730 \mathrm{~cm}^{-1}$, olefinic band at $1,625 \mathrm{~cm}^{-1}$, primary and secondary alcohols functionalities bands at 1,103 and $1,033 \mathrm{~cm}^{-1}$ as well as the peaks around 3,000 and $1,400 \mathrm{~cm}^{-1}$ attributable to aliphatic $\mathrm{C}-\mathrm{H}$ stretching and bending modes [Magné et al. 2005; Culioli et al. 1999). By comparing the spectrum of CONPs with that of the alga extract, we can conclude that the two spectra are similar in their spectral features. There is no question, therefore, that the compound on the surface of CONPs has a very close chemical composition to the alga extract if not identical. It was found that many peaks obtained by the alga extract have been repeated in the FTIR spectrum of CONPs with changes in the position as well as in the intensity of absorption bonds. After the synthesis of CONPs, the absorption peaks at 3,413,1,625,1,103 and $1,033 \mathrm{~cm}^{-1}$ corresponding to $\mathrm{OH}, \mathrm{C}=\mathrm{C}$ and $\mathrm{C}-\mathrm{O}$ observed in plant extract get narrower and shifted to higher frequency regions, while those at around 3,000 and $1,400 \mathrm{~cm}^{-1}$ attributable to aliphatic $\mathrm{C}-\mathrm{H}$ stretching and bending modes decreased in intensity and shifted to low frequency regions. In addition the disappearances of $v_{\mathrm{C}=\mathrm{O}}$ stretching vibration of the $\alpha, \beta$ - unsaturated ketone at $1,730 \mathrm{~cm}^{-1}$ confirm that the reduction and the stabilization of CONPs proceed via these groups which confirm that water-soluble compounds such as diterpenoids are present in Bifurcaria Bifurcata 
extract has the ability to perform dual functions of reduction and stabilization of CONPs. A similar observation has been reported by several works [Shankar et al. 2004; Rajathi et al. 2012; Kiruba Daniel et al. 2012).

The antibacterial activity of alga extract and CONPs was examined against both Gram-negative and Gram-positive bacteria by using disc diffusion test. The radial diameter of the inhibition zone of $E$. aerogenes and $S$. aureus by CONPs are 14 and $16 \mathrm{~mm}$, respectively (Fig. 7). The discs filled with alga extract alone did not show any zone of inhibition suggesting that at the concentration used for synthesis of CONPs, alga extract showed no antibacterial activity, but CONPs synthesized from the extract exhibited good antibacterial activity. Based on these results, it can be concluded that these synthesized CONPs had significant antibacterial action on both of the Gram classes of bacteria, which may be attributed to the greater abundance of amines and carboxyl groups on their cell surface and greater affinity of copper ions toward these groups (Beveridge and Murray 1980). CONPs show efficient antibacterial property due to their extremely large surface area, which provides better contact with microorganisms. Copper ions released subsequently may bind with DNA molecules and lead to disorder of the helical structure by cross-linking within and between the nucleic acid strands. Copper ions inside bacterial cells also disrupt biochemical processes [Kim et al. 2000; Stohs and Bagchi 1995). The exact mechanism behind is not known and needs to be studied further. Furthermore, the Gram-negative bacteria seemed to be more resistant to CONPs than Gram-positive bacteria. This observation is in agreement with earlier studies (Zarrindokht and Chehrazi 2011). It was earlier reported that the interaction between Gram-positive bacteria and nanoparticles was stronger than that of Gram-negative bacteria because of the difference in cell walls between Grampositive and Gram-negative bacteria. The cell wall of E. aerogenes, which consists of lipids, proteins and

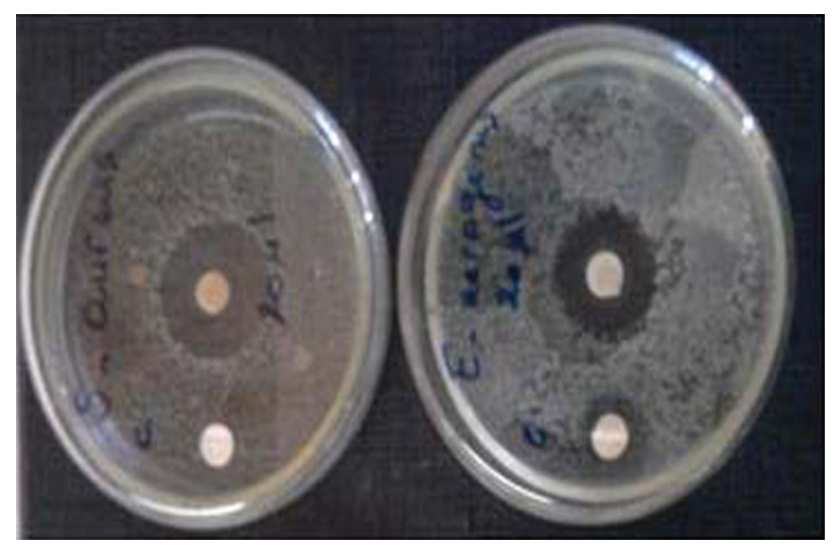

Fig. 7 Antibacterial assay: zone of inhibition against Enterobacter aerogenes and Staphylococcus aureus lipopolysaccharides (LPS), provides effective protection against biocides. However, the cell wall of Gram-positive bacteria, such as $S$. aureus, does not consist of LPS (Speranza et al. 2004).

\section{Conclusion}

In the present work, we first report an eco-friendly and convenient method for the synthesis of CONPs using brown alga (Bifurcaria bifurcata) extract. No chemical reagent or surfactant template was required in this method, which consequently enables the bioprocess with the advantage of being environmental friendly. The developed nanoparticles were characterized by UV-vis, TEM, XRD and FTIR measurements and showed good antibacterial activity. An important potential benefit of the described method of synthesis of nanoparticles using marine algae is that they are quite stable in solution and this is a very important advantage over other biological methods currently in use. This biosynthesis technique can be a promising method for the preparation of other metals and metal oxide nanoparticles and can be valuable in environmental, biotechnological, pharmaceutical and medical applications.

Open Access This article is distributed under the terms of the Creative Commons Attribution License which permits any use, distribution, and reproduction in any medium, provided the original author(s) and the source are credited.

\section{References}

Ahmadi SJ, Outokesh M, Hosseinpour M, Mousavand T (2011) A simple granulation technique for preparing high-porosity nano copper oxide(II) catalyst beads. Particuology 9:480-485

Amico V (1995) Marine brown algae of family Cystoseiracea: chemistry and chemotaxonomy. Phytochemistry 39:1257-1279

Beveridge TJ, Murray RG (1980) Sites of metal deposition in the cell wall of Bacillus subtilis. J Bacteriol 141:876-887

Blunt JW, Copp BR, Munro MHG, Northcote PT, Prinsep MR (2005) Marine natural products. Nat Prod Rep 22:15-61

Borgohain K, Murase N, Mahamuni S (2002) Synthesis and properties of $\mathrm{Cu} 2 \mathrm{O}$ quantum particles. J Appl Phys 92: 1292-1297

Chiang CY, Aroh K, Ehrman SH (2012) Copper oxide nanoparticle made by flame spray pyrolysis for photoelectrochemical water splitting e Part I. CuO nanoparticle preparation. Int J Hydrogen Energy 37:4871-4879

Combaut G, Piovetti L (1983) A novel acyclic diterpene from the brown alga Bifurcaria bifurcata. Phytochemistry 22:1787-1789

Culioli G, Daoudi M, Mesguiche V, Valls R, Piovetti L (1999) Geranylgeraniol-derived diterpenoids from the brown alga Bifurcaria bifurcata. Phytochemistry 52:1447-1454

Daniel MC, Astruc D (2004) Gold nanoparticles: assembly, supramolecular chemistry, quantum-size related properties, and applications towards biology, catalysis and nanotechnology. Chem Rev 104:293-346 
Gunalan S, Sivaraj R, Venckatesh R (2012) Aloe barbadensis Miller mediated green synthesis of mono-disperse copper oxide nanoparticles: optical properties. Spectrochim Acta A 97:1140-1144

Honary S, Barabadi H, Fathabad EG, Naghibi F (2012) Green synthesis of copper oxide nanoparticles using penicillium aurantiogriseum, penicillium citrinum and penicillium wakasmanii. Digest J Nanomater Biostruct 7:999-1005

Jani AMM, Losic D, Voelcker NH (2013) Nanoporous anodic aluminium oxide: advances in surface engineering and emerging applications. Prog Mater Sci 58:636-704

Kao MJ, Lo CH, Tsung TT, Wu YY, Jwo CS, Lin HM (2007) Copperoxide brake nanofluid manufactured using arc-submerged nanoparticle synthesis system. J Alloy Compd 434-435:672-674

Kim JH, Cho H, Ryu SE, Choi MU (2000) Effects of metals ions on the activity of protein tyrosine phosphate VHR: highly potent and reversible oxidative inactivation by $\mathrm{Cu}^{2+}$ ion. Arch Biochem Biophys 382:72-80

Kiruba Daniel SCG, Nehru K, Sivakumar M (2012) Rapid biosynthesis of silver nanoparticles using Eichornia crassipes and its antibacterial activity. Curr Nanosci 8:1-5

Kooti M, Matouri L (2010) Fabrication of nanosized cuprous oxide using Fehling's solution. Trans F Nanotechnol 17:73-78

Krithiga N, Jayachitra A, Rajalakshmi A (2013) Synthesis, characterization and analysis of the effect of copper oxide nanoparticles in biological systems. Ind $\mathrm{J}$ Ns 1:6-15

Magné AO, Culioli G, Valls R, Pucci B, Piovetti L (2005) Polar acyclic diterpenoids from Bifurcaria bifurcata. Phytochemistry 66:2316-2323

Montferrand CD, Huc L, Milosevic I, Russier V, Bonnin D, Motte L, Brioude A, Lalatonne Y (2013) Iron oxide nanoparticles with sizes, shapes and compositions resulting in different magnetization signatures as potential labels for multiparametric detection. Acta Biomater 9:6150-6157

Nassar NN, Husein MM (2007) Effect of microemulsion variables on copper oxide nanoparticle uptake by AOT microemulsions. J Colloid Interf Sci 316:442-450

Rahman A, Ismail A, Jumbianti D, Magdalena S, Sudrajat H (2009) Synthesis of copper oxide nanoparticles by using Phormidium cyanobacterium. Indo J Chem 9:355-360

Rajathi FAA, Parthiban C, Kumar VG, Anantharaman P (2012) Biosynthesis of antibacterial gold nanoparticles using brown alga, stoechospermum marginatum (kützing). Spectrochim Acta A 99:166-173

Ramgir N, Datta N, Kaur M, Kailasaganapathi S, Debnath AK, Aswal DK, Gupta SK (2013) Metal oxide nanowires for chemiresistive gas sensors: issues, challenges and prospects. Colloids Surf A Physicochem Eng Asp. doi:10.1016/j.colsurfa.2013.02.029
Schmid G (1992) Large clusters and colloids metals in the embryonic state. Chem Rev 92:1709-1727

Shalana AE, Rashada MM, Yu Y, Cantub ML, Abdel-Mottaleb MSA (2013) Controlling the microstructure and properties of titania nanopowders for high efficiency dye sensitized solar cells. Electrochim Acta 89:469-478

Shankar SS, Rai A, Ahmad A, Sastry M (2004) Rapid synthesis of $\mathrm{Au}, \mathrm{Ag}$, and bimetallic Au core-Ag shell nanoparticles using Neem (Azadirachta indica) leaf broth. J Colloid Interf Sci 275:496-502

Speranza G, Gottardi G, Pederzolli C, Lunelli L, Canteri R, Pasquardini L, Carli E, Lui A, Maniglio D, Brugnara M, Anderle M (2004) Role of chemical interactions in bacterial adhesion to polymer surfaces. Biomaterials 25:2029-2037

Srivata M, Singh J, Mishra RK, Ojha AK (2013) Electro-optical and magnetic properties of monodispersed colloidal $\mathrm{Cu}_{2} \mathrm{O}$ nanoparticles. J Alloys Comp 555:123-130

Stohs SJ, Bagchi D (1995) Oxidative mechanisms in the toxicity of metal ions. Free Radic Bio Med 18:321-336

Swarnkar RK, Singh SC, Gopal R (2009) Optical characterizations of copper oxide nanomaterial. In: Proceedings of the ICOP International Conference on Optics and photonics. CSIO, Chandigarh

Valls R, Banaigs B, Piovetti L, Archavlis A, Artaud J (1993) Linear diterpene with antimitotic activity from the brown algae Bifurcaria bifurcate. Phytochemistry 34:1585-1588

Vijayakumar R, Elgamiel R, Diamant Y, Gedanken A (2001) Sonochemical preparation and characterization of nanocrystalline copper oxide embedded in poly(vinyl alcohol) and its effect on crystal growth of copper oxide. Langmuir 17:1406-1410

Volanti DP, Keyson D, Cavalcante LS, Simoes AZ, Joya MR, Longo E, Varela JA, Pizani PS, Souza AG (2008) Synthesis and characterization of $\mathrm{CuO}$ flower-nanostructure processing by a domestic hydrothermal microwave. J Alloys Comp 459:537-542

Wang J, Yang J, Sun J, Bao Y (2004) Synthesis of copper oxide nanomaterials and the growth mechanism of copper oxide nanorods. Mater Des 25:625-629

Yin M, Wu CK, Lou Y, Burda C, Koberstein JT, Zhu Y, O'Brien S (2005) Copper oxide nanocrystals. J Am Chem Soc 127: 9506-9511

Zarrindokht EK, Chehrazi P (2011) Antibacterial activity of $\mathrm{ZnO}$ nanoparticle on Gram-positive and Gram- negative bacteria. Afr J Microbiol Res 5:1368-1377

Zhang Y, Wang S, Li X, Chen L, Qian Y, Zhang Z (2006) CuO shuttle-like nanocrystals synthesized by oriented attachment. J Cryst Growth 291:196-201 